\title{
The \#MeeToo Movement as an e-Discourse: Social and Legal Effects
}

\author{
Marcel Danesi, Laura Ervo, Lukas Kindberg \& Kerstin Nordlöf
}

\section{The Goals of \#MeToo}

The phrase "MeToo" was first used on Myspace in 2006 by activist Tarana Burke. It quickly became the moniker for a social-media-based socio-political movement unified ideologically by the \#MeToo hashtag and gaining momentum after media personality Alyssa Milano posted an appeal on Twitter on October 15, 2017, following sexual abuse allegations against cinema mogul Harvey Weinstein in early October of 2017: "If all the women who have been sexually harassed or assaulted wrote 'Me too' as a status, we might give people a sense of the magnitude of the problem" (Milano 2017). On the following day, Milano's post was retweeted over three hundred thousand times (Caputi, Noble, and Ayers 2010), spiking two days later with Harvey Weinstein's resignation, when it reached nearly eight hundred thousand tweets. During 2018, it was tweeted over nineteen million times (Anderson and Toor 2018).

As a movement designed to raise consciousness of the sexually-based mistreatment of women (especially in the workplace) and to assist sexual assault survivors (Burke, n.d.), \#MeToo quickly evolved into a powerful worldwide movement championing women's issues (Buxton 2018), extending beyond its origins as a social media and hashtag activist movement in the US, through which survivors of sexual harassment and assault - the majority of them women-identifying - have been able to share their experiences and ignite public outrage against prominent names in all spheres of society. Debates on the deleterious effects of sexually-motivated abuses of power and harassment against women, via \#MeToo, have led to a new era of transnational feminism, as survivors and their supporters share their stories electronically through the Internet (Me Too Rising, n.d.). The lasting political-social-legal effects of the movement are still to be determined, but the fact remains that it has allowed women to voice their concerns in new effective ways through the Internet, with a lessened fear of reprisals (Nicolaou and Smith 2019, Santucci 2020); as such, it constitutes a veritable ideological shift in giving women a powerful new voice throughout the world.

Our purpose is to examine the impact of the e-discourse associated with the \#MeToo movement on the outcome of specific legal cases in Sweden and America, as a template for assessing the broader effects it has had on society in the domain of gender discrimination. The study is interdisciplinary. The authors represent the disciplines of jurisprudence and semiotics. Comparative method, legal dogmatics, legal linguistics, linguistic anthropology as well as 
semiotics are used as generic analytical tools for discussing the topic from different perspectives. We argue that, while the voices of abuse survivors have been given an equivalence status to those of people in positions of power, they have also led to cases of trial-by-social-media that have had unwanted consequences. Through its effective hashtag intertextuality (crossreferences, allusions, etc. to relevant themes, texts, ideas), \#MeToo has emerged to oppose and challenge dominant patriarchally-based systems of discourse and the law; but it has also unwittingly led to the loss of reputation and even life of the targets of the discourse campaigns through strategies of shaming and blaming. So, although \#MeToo has led to the destigmatization of experiences of sexual harassment and assault, by giving survivors a powerful means to articulate their experiences, it has also had negative outcomes. The latter situation is the reason, perhaps, why the movement has somewhat receded today, especially in the face of urgent issues such as climate change and COVID-19.

\#MeToo has also come under fire for its prioritization of upper-class, white voices, which are seen, literally, as the "faces" of the movement, despite the fact that it was initially founded by and for Black and Brown women (Charles 2018, Harris 2018). Additionally, the most recognizable figures, with their personal critiques and protestations, are American ones, even though \#MeToo has spread internationally, with correlative movements such as \#Masaktach in Morocco and the transnational Muslim \#MosqueMeToo one (Warshawsky 2019), pushing for changes outside of those that apply to Western societies. Moreover, the movement is being expanded to include the plight of male victims of abuse as well as victims of other genders. In all instances, the discourse strategies that stifle the achievement of justice are the same, forming a "polyphonic unity," to use Mikhail Bakhtin's (1981) notion, as they come together in terms of common experiences and purpose.

As mentioned, it was activist Tarana Burke who founded the movement in 2006, with JustBeInc to aid survivors of sexual harassment and racial discrimination (Nicolaou and Smith. 2019), after an experience she had as a youth worker, in which she found herself unable to admit to a young girl that she was herself a victim of abuse. In her words: "I watched her put her mask back on and go back into the world like she was all alone and I couldn't even bring myself to whisper... me too" (Burke, n.d.). The latter phrase quickly spread as a rallying cry among women in online contexts, aiming to reduce the stigma of being a survivor and thus combatting the sense of isolation that it had previously engendered.

Since then, \#MeToo has had significant impacts on the conduct of legal cases concerning sexual harassment and assault, as well as on reforms to existing criminal legislation. But despite the latter, the number of individuals accused of committing sexually-based assaults has hardly diminished, and may have even increased. For example, in Sweden, statistics show higher numbers of reported sexual assaults than in the past, while the number of legal 
accusations and allegations continue to remain low, especially when compared with other European countries (Brå 2020:2). As a consequence, the question arises as to whether or not the relevant criminal legislation has been effective in counteracting sexual crimes. The \#MeToo movement may thus be influencing legal responses in disparate ways according to national context. The movement may have also indirectly affected a basic premise of democratic cultures - namely, to equally protect the personal integrity of all members of society, regardless of gender, race, ethnicity, and ideology. It has impugned the principle of the presumption of innocence by generating rumours, conspiracy theories, and false accusations. This has been highlighted by a number of famous cases, to be discussed below.

\section{The \#MeToo Movement: e-Discourse Structures and Strategies}

In January 2017, on the heels of the Women's March the day after exPresident Donald Trump's inauguration, and in the wake of allegations of sexual misconduct against media personalities such as Harvey Weinstein, Roy Price, and Bill O'Reilly, among others, \#MeToo gained significant momentum as a hashtag-inspired movement designed to allow for the expression of a commonality of experiences and perspectives on the part of all women. An explosion of allegations of sexual abuse and harassment followed immediately thereafter in all spheres of public life, involving celebrities, politicians, CEOs, artists, doctors, and other public figures (Nicolaou and Smith 2018). Between January 2017 and June 2018, 417 highprofile individuals were subjected to accusations with identifier hashtag, with 193 resigning or dismissed from their positions and another 122 being suspended (Green 2018). The stated mission of the movement has always been to help sexual abuse survivors heal by connecting them to the resources they might need (Harris 2018), and to give their voices social value, challenging the oppressive practices of established sexual politics. The words of one woman encapsulate the ethos and objectives of the movement: "This is not only a significant moment in history; it's a significant moment in internet history: Me Too marks a time when sexual assault survivors everywhere turned the internet into a platform for their voices and perspectives to be heard and respected" (Buxton 2018).

The language of the movement is key to decoding what it aims to do and how it pursues its objectives. Using Pierre Bourdieu's notion of habitus, language in such situations operates as "structured structures predisposed to function as structuring structures," which he explains as "principles which generate and organize practices and representations that can be objectively adapted to their outcomes without presupposing a conscious aiming at ends or an express mastery of the operations necessary in order to attain them" (Bourdieu 1980:53). The goal of \#MeToo is ultimately to dismantle the existing habitus (the structured structures of patriarchy) that has historically 
undermined the victims of sexual abuse by allowing the abusers to use the "structures" advantageously against the victims. The \#MeToo movement has led to restructuring of this biased system, by assigning discourse agency to the victims (Ortner 2006:132). It thus constitutes a counterculture movement that centres on women's plight and on their struggle for autonomy from the dominant male-centred discourse; its effectiveness lies in the power of ediscourse itself, which allows victims to construct their representations of sexual abuse as a collective (rather than as isolated) experience. In effect, each post becomes a rallying cry via retweeting and various other viral messaging systems. Changing social practices and perspectives, such as the perception of gender, requires a change in the language that discusses and frames them (Danesi 2016:6) - the \#MeToo movement set out to do just this.

Over time, the hashtag posts and messages coalesce into an overall ediscourse, based on terse and nuanced expressions, steering users towards short and committed speech that magnifies individual cases through hashtag themes as typical rather than exceptional. A perusal of the tweets under the keyword search of the hashtag \#MeToo (Keyword Search 2020) has revealed how this comes about-phrases such as "I believe [woman's name]" or "[man's name] has been accused of sexual assault," assign emotive force to the accusation, ascribing unconscious value to women survivors, whether or not the allegations is true. The tweets take the form of assertives, stating allegations and experiences as part of collective expression in an attempt to influence others to "attend to [the] belief" (Danesi 2016:13). Other speech strategies noted from our internet search has revealed a frequent use of expressives, which communicate the speaker's opinion and emotional reaction towards the allegations, and of representatives, which highlight the position of the speakers in the overall debate on sexual politics. Also significant are declarations which place responsibility for assault on individuals, named or unnamed, imploring others to speak out and act upon them.

Given that Twitter served as the original site of the movement, hashtags have, in effect, become the semiotic and discourse keys to unlocking the movement's conceptual code. For instance, hashtags such as "\#BelieveWomen" or "\#BelieveSurvivors," emphasize a collective belief in women's and survivors" experiences. "\#MeToo" is itself an assertion of "inclusion" on the platform, revealing the discourse strategy which suggests the "collapsing [of] difference by 'textualizing' relations of equivalence between them," as Fairclough (2003:88) puts it. Overall, the thematics of the hashtags themselves are used to emphasize the solidarity of women against those who seek to keep them subjugated. The choice of "survivors" rather than "victims" is an empowering one, highlighting strength, defiance, and courage juxtaposed against a previous discourse of weakness and victimization, which has been traditionally used to devalue survivors. Such keywords have crystallized into a new feminist ideology, marked by "intersectionality" 
(common intersecting experiences) and "equality," to counteract the previous discourse of oppression. This prevailing discourse strategy gives the movement greater sustainability, providing an emotional framework that groups survivors together rather than isolating them, therefore broadening people's conceptual horizons (Bourdieu 1980:52) by establishing a more equitable social system that foregrounds the experiences of sexual victims.

The hashtags appear not only on followers' feeds, but also in lists or collections with tagged content, therefore connecting them to a broader conversation of survivorship and activism based on their themes. Hashtags such as \#BelieveWomen and \#BelieveSurvivors (among others) draw upon the meanings of every other tweet within that collection, reinforcing the unity of referential structure, not only directly alluding to other texts within these groupings, but also actively incorporating them into the ever-broadening ediscourse. Hashtags operate as a link to this, having evolved into an effective discourse-semiotic tool in raising social awareness on the plight of sexual abuse survivors.

\section{Legal Effects: The Example of Swedish Criminal Law}

\#MeToo has had significant repercussions on various legal systems throughout the world, in addition to changing the social perceptions of sexual victims. But the movement has also brought about counter-effects on how certain legal principles are applied in various situations, such as the principle of "innocent until proven guilty." This principle implies that a person's guilt must be evaluated objectively, in order to determine if an accusation has been made rightfully or wrongfully.

Legal systems change not only with national interests in mind, but also in accordance with international political-legal agreements. Criminal law contains the relevant statutes passed into law by national legislatures as specific mechanisms for protecting citizens against harm, including breeches of personal integrity and for ensuring equal treatment under the law. The latter vary from one legal system to another depending on the political system in place (for example, democracy), perceptions of what "citizen equality" means in historical and cultural terms, and so on. In many systems, property is considered more valuable to protect than other interests, along with personal integrity, with the gender and age characteristics and attendant rights of the alleged law-breaker encoded into the systems. As a result, the legal definition of sexual assault varies substantively from one system to another and even from era to era. In Sweden, for example, the sexual assault of a child by an adult was criminalized in 1937 (Diesen 2013:141) and sexual assault within marriage in 1965, by the Swedish Penal Code (The 1864 Penal Code 15:12, Berglund 2007:235). In 2005, the Swedish government eliminated the requirement of violence in a sexual assault against a child, as well as the child's lack of consent (that is, not knowing any better or being in a situation of dependency on the offender) (Government Bill 2004/05:45:5). In 2018, the 
Swedish Criminal Code changed its definitions of sexual assault and sexual abuse, so as to protect personal integrity by stipulating conditions under which the assault or abuse was consensual or not (SFS 2018:618 The Criminal Code 6:1-3, Government Bill 2017/18:177:22). Needless to say, in an international context, not all criminal codes have been adjusted accordingly. For example, in the current Criminal Code of the Russian Federation, Article 16 does not criminalize domestic violence or protect the personal integrity of the victim in many abuse situations, which in most cases involves a woman.

The Swedish Criminal Code espouses several fundamental principles of criminalisation, which aim to safeguard principles, such as the principle of legality, the innocent until proven guilty principle, the principle of humane treatment, and the principle of proportionality (Asp 2010:62). The emergence of the \#MeToo movement has cast light on the discrepancies and biases of criminal laws defining sexual assault and sexual abuse within this Swedish and similar systems, which it claims do not protect the personal rights of survivors by not assigning sufficient (if any) criminal responsibility to the alleged perpetrator, in many cases. But, at the same time that the movement has led to changes in attitude towards victims, portraying them as survivors, it has also produced infelicitous consequences - a simple accusation of sexual abuse against a person today, whether true or not, has not only subjected that person to social marginalization at the very least, but also often to loss of reputation and income - a predicament that has at times led to suicide (Frände 2018) - to be discussed below.

According to the Swedish Criminal Code, a criminal act can be defined by either commission or omission (SFS 1962:700 The Criminal Code 1:2). Moreover, an act may not be considered criminal, even if it brings about personal damage, in specific situations. For instance, an act causing personal harm may be accidental or else performed by mutual agreement, as in an emergency when what might be considered to be criminal under different circumstances is considered legitimate because it can save life. Acts of selfdefence are also typically excluded from criminal prosecution under specific circumstances (Jareborg 2016:114). These principles have not been impugned by the \#MeToo movement. It is the principle of "innocent-until-provenguilty," espoused by most legal systems, that is most at risk as a result of public events brought about by \#MeToo e-discourses. Since the only two parties involved in a sexual abuse case are, normally, the accuser and the accused, it has always been difficult to apply this principle to many situations. In the past, and to some extent even now, the account of the woman was shaped stereotypically by superficial matters associated with gender perceptions, such as how she dressed (for example, provocatively) or what she may have done in a sexual way to provoke the abuse. Even if this situation has changed legally, with such aspects now being excluded from a sexual abuse trial, \#MeToo has been instrumental in arguing that unconscious 
gendered imbalances and biases nevertheless persist in the conduct of such trials.

According to the Swedish Criminal Code the punishment of a crime must be based on both the principle of proportionality between the crime and the penalty - that is, on a penalty between being consistent with the severity of the crime and the degree of legal intervention to be enacted - and the principle of equality, whereby equally serious crimes should be punished equally. The latter principle also implies that serious crimes should be punished more severely than less serious one (Asp 2010:67). In practice, such principles imply that penalties should be non-intrusive and sensitive to the rights of the accused person (Asp 2010:68). In the case of sexual assaults, currently the Swedish Criminal Code assigns a penalty of imprisonment between six months and ten years, on the basis of the severity of the crime (SFS 2018:618, Swedish Criminal Code 6:1-3). Similar principles and penalties cross national boundaries. International agreements, such as the Declaration on the Elimination of Violence against Women of 1993 and the Council of Europe Convention on preventing and combating violence against women and domestic violence of 2011, are examples of how the entire world has been responding to the endemic problem of sexual assault and sexual abuse that has existed for many years. The Swedish Criminal Code has been amended on several occasions in relation to crimes of violence and sexual abuse long before \#MeToo. But the movement has been instrumental in promoting responses across the world, turning the spotlight on the need to address violence against women concretely and effectively.

The movement has clearly had an impact on perceptions and attitudes with regards to long-standing transgressions against women, fleshing out into the open deficiencies in legal systems and how to remedy them. Through the effectiveness of its e-discourse, strategies, \#MeToo has engendered a worldwide debate that has influenced legal structures regarding sexuallybased crimes. The problem is that, although \#MeToo's influence has led to actual trials, its courtroom is mainly the internet and its social media architecture - a medium that excludes such well-established legal-ethical practices as preliminary investigations by the police and the use of forensic evidence. Given the selective accusatory information of the relevant ediscourses, which makes it virtually impossible to verify as evidentiary, men have been wrongfully accused and put into the position of being unable to make their case for innocence except by counter-accusing the accuser of defamation (SFS 1962:700 The Criminal Code chapter 5). The "virtual cases" tried on Twitter seldom appear in real courtrooms because of the high standards for criminal responsibility enshrined in the law, and the dangers of the accuser of being counter-accused. The end result of virtual trials is shaming, rather than genuine legal procedures. As much as \#MeToo has changed the discourse and perceptions on sexual crimes, it has done so at times by ignoring fundamental principles of the law. It remains to be seen 
when the balance between discursivity and legality will be reached within the movement.

\section{Influences on Procedural Law}

As discussed, \#MeToo has been a powerful social movement based on the power of intertextuality in e-discourse platforms; but, this situation has also led to "trials-by-social-media," based on selective information and intensive hashtag allegation campaigns leading to cases that have been tried on the internet, precluding the accused's right to 1) a fair trial and 2) the right to be heard. There were none of the following: 1) presumption of innocence, 2) favour defensionis, and 3) equality of arms (whereby both sides must have equal procedural instruments), which are fundamental procedural principles There is always a risk that trial by media - in this case by social media - and its effects of public opinion shapes the views of decision makers, especially if they are lay members and jurors who do not have professional training that impels them to keep their own emotions from influencing decision making. Also, the practice of 4) best evidence, was watered down with respect to which witnesses were involved. The verdict was given in advance by people who did not have 5) jurisdiction. Ignoring this set of basic legal principles is typical of trial-by-media events (see for instance Fredman 2002:303-309).

\#MeToo has, consequently, only put procedural practicalities at risk, but also turned procedural principles upside down, especially whenever \#MeToodiscourses have been accepted blindly and taken seriously. Unfortunately, this seemed to be the general pattern during that time when \#MeToo online trials were booming. Bolstered by the voices of media celebrities, socialites, and other kinds of influential figures, who have taken an active role in the movement, providing testaments of their own travails and their credibility has at times overshadowed legal testability. A powerful strategy is to identify alleged perpetrators of sexual abuse or assault in a public way through social media platforms - going against the right to privacy of those being accused as well as the innocence principle. Such behaviour negatively affects legal procedures as a whole. Compared with the traditional media trials, the \#MeToo social media trial system was more effective because it allowed the victim to air grievances directly to the masses.

As a result, the \#MeToo e-discourse became global, gaining broad publicity, impugning the right of the accused perpetrator of sexual crimes to legal privacy (about privacy see for instance Melander 2019:961-962). In legal court procedures, there is no need to produce sensationalistic reports. In contrast to real courtroom proceedings, trial-by-social-media 6) does not afford a privacy protection.

Moreover, the relevant cases happened a long time ago. Therefore, it was even more difficult to determine which of the allegations were true and which ones probably were false. There was thus 7) no limitation of prosecution, which has two aspects to it. First, the rule limited time period in which to 
collect the relevant evidence. If the allegation happened a long time ago, it is difficult to get appropriate proof and evidence. Often, such cases end with indeterminate judgments. Second, and more importantly, there is a moral aspect to long-standing cases. If something has happened a very long time ago, the moral need to find out the truth and to conduct an investigation is no longer that strong if at all necessary. Something, which has happened a very long time ago is perceived as water under the bridge. The police, prosecutor, and victim have the obligation to conduct the trial in a reasonable amount of time. If not, the case should not be opened at all. This is based on the idea of finality according to which uncertainty causes more moral damage than correcting the injustice.

In cyberspace the accusation remains indefinitely, even if the case happened a long time ago, and thus perceived as ongoing rather than unresolved. This is again a problem from the perspective of procedural principles. Namely, a fair trial must happen in a reasonable time (see for instance Ervo 2005:109-154, Ervo \& Dahlqvist 2014:273-274 and Kastula 2009:21-65). There are two reasons for this: to guarantee the best evidence and the best possible decision making, and to minimize the suffering of the parties who often think that the trial is stressing even more than the original crime (Rouhiainen 2014:19-20).

It is relevant to note that the \#MeToo-identified guilty parties were socalled "good enemies". Nils Christie and Kettil Bruun launched this concept in the 1980s (Christie \& Bruun 1986:12). It is perceived as a way to "let off steam" and aggressions in an acceptable way. When criticising "good" enemies, people can feel how good they are themselves in comparison. By doing and feeling so, they can take their aggressions out on enemies and feel their own superiority. However, not all enemies are "good" in this sense. To be a good enemy, the person needs to fulfil the following criteria. First, the enemy needs to be clearly defined by common folk, such as, for instance drug users as contrasted with people who use "just" alcohol. Second, there should be no real risk for normal people or their friends to be passed as drug users or it should not be too risky to do so. That kind of limited group of outsiders is safe, However, people who abuse alcohol are not easily identifiable. So, there is a risk of anyone being identified as an alcoholic. The category is then no longer an assignable to a limited group of outsiders, and such "good enemies" can no longer be used as safety valves (Laitinen 2002). The groups that are "good enemies" vary according to era. Drug users were such a group in the 1970s. Given that such models of ascribed criminality are now subsiding, along with \#MeToo hashtag trials, it is still relevant to look retrospectively on the effects that the movement has brought about on legal procedures and their relation to public perceptions. Media trials fulfill an immediate need for justice and atonement, whereas the usual court trial, take more time and involve arguments on both sides of a case, with judges, defense attorneys, and prosecutors negotiating outcomes of a case, which can be seen as 
downplaying public feelings such as the need for atonement One aspect of \#MeToo online justice is that it has sensitized courtrooms to be much more attuned to the need to respond more quickly and effectively to real accusations. It can therefore be asked if the system is too complicated, too obscure, too scary. Clearly, what the \#MeToo phenomenon has made clear is that the protection of victims and victimizers needs to be totally re-examined in the context of ongoing social justice movements (see for instance Ervo 2005:241-244 and Vuorenpää 2001:231-246).

\section{Negative Outcomes: Highly-Publicized Cases in Sweden and America}

As implied in the discussion above, a central problem with hashtag trials is that they may not be based on the same principles of law that are applied in real courtrooms, and may be often used as a forum for personal revenge schemes. In effect, the \#MeToo movement has had significant impacts on the general structure of current laws, seemingly at odds with each other, as cases of paramount interest to the general public have shown, especially in affecting the legal relations between the accuser and the accused. Swedish law, for instance, provides legal mechanisms to ensure protection against sexual abuse and against the defamation that may result from abuse accusations. When proven guilty in a court of law, under the law sexual offenders face harsh punishment. A requirement in sexual abuse cases is ascertaining the identity of the offender - a requirement which is afforded under oath to the sexually abused person. Certain limits are nonetheless placed on this fundamental right. For instance, the accuser must place her allegation before legal authorities who allow the accuser to provide evidentiary stipulations for identifying the perpetrator. Now, while \#MeToo has raised awareness to the plight of abused survivors, it has also allowed accusers to skip around this legal requirement, conferring to any accuser the right to identify supposed offenders publicly through social media, replacing the legal system in passing judgement in individual cases and its mechanisms for protecting both the accuser and the accused.

A remarkable case-in-point, which occurred during peak interest in the \#MeToo-movement, from 2017-2019, concerned allegations against a famous Swedish television host that he had sexually assaulted one of his coworkers, eleven years prior to proceedings in the Court of Appeal. It has been called "the first \#MeToo judgement in Sweden" (Svea Hovrätt, B 6863-18). According to the plaintiff, the TV host had violently assaulted her sexually without her consent. The statute of limitations had precluded pursuance of the allegation in full. A former co-worker, who was one of the witnesses against the accused, came forward to present the case on social media platforms frequently. One of her posts contained a provocative picture of the TV host along with the tagline "[Our] own Harvey Weinstein \#MeToo." Due to the long period of time that had passed between the alleged sexual assault and the 
legal proceedings, neither criminal intent nor the alleged actions could be proven beyond a reasonable doubt, allowing the accused had to be freed from all charges. However, the proceedings themselves, along with vast interest in the case on the part of both conventional media (newspapers and broadcasting) and social media, brought about major negative consequences for the accused. He lost his employment and the prospect of engaging in future projects. The spread of the allegations and the damages to the defendant's reputation cannot be overstated. The TV host was not proven guilty in a court of law, but he had to live with a guilty verdict nonetheless assigned to him, not by a judge or a jury, but by the media universe.

Following the case, several news agencies were heavily criticized for their active part in the public humiliation of the TV host. Six of these (Dagens Nyheter, Svenska Dagbladet, Expressen, Aftonbladet, Metro and Hänt $i$ veckan) were either "blamed" or "faulted" for their involvement by the Media Council (part of the Media Ombudsman), mainly due to lack of factual support for claims of criminal behavior prior to the criminal proceedings. According to self-regulatory industry standards there were several severe ethical violations related to the case. However, no Swedish court has yet tried the agencies for criminal defamation and, thus, no restitution has been made. The case showed that the identification of a purported criminal offender via \#MeToo justice garnered harsh consequences for the accused even though a non-guilty verdict was passed by the courts.

Another high-profile case was the one against a man, dubbed "Kulturprofilen," which started when on November 21, 2017 after eighteen women co-wrote an article for Dagens Nyheter, later published in book-form, accusing a proprietor of a prestigious "culture-club" of several crimes of sexual assault, threats, violence, and harassment (Gustavsson 2019). Following publication of the article, the man was charged on two counts of sexual assault and eventually sentenced for both, after losing appeals (Stockholms tingsrätt, B 15565-17 and Svea Hovrätt, B 9085-18). Only one of the eighteen accusers received compensation after the criminal proceedings because, as in the case above, a long time had passed between the alleged actions and the court proceedings. The point here is that the attacks against assailants from both conventional and social media laid the ground for pursuing his prosecution. A major difference between this case and the one above, apart from the different juridical outcomes, was the fact that the accused was given ample time to dispute the charges against him by the media before publication. However, in the end, the man was "sentenced" by both the courts and the public.

A third well-known case of a \#MeToo-related case concerns a deceased theater director. Due to extensive, but often unsubstantiated, media scrutiny of his alleged sexual misconduct as head of Kulturhuset Statsteatern, he was pushed out of employment. A few months later, he ended his own life in a supposed act of hopelessness. No proceedings, either of a criminal or civil 
law nature, have come before the courts as of now. However, the Media Ombudsman, through the Media Council, heavily and extensively criticized the news outlet responsible for the original reports (Aftonbladet, exp. nr. 12/2019, dnr. 18176). In December 2017, the news agency had launched a series of detailed reports on the theater director's purported character as "an unsteady dictator." The director had not been offered any opportunity to respond to the charges, even though some of the alleged events had occurred many years prior to the reports. The Media Council also concluded that, while initially plausible, many of the claims in the reports were utterly groundless and were, in fact, later disproven. Among those claims were the suggestions that the theater director had "forced an actress to carry out an abortion," that he had "forced a young man to rehearse in the nude," and that he had "effectively silenced matters of physical violence where criminal charges would otherwise have been made." Some of the reports remained available online for more than six months after having been disproven or contradicted. However, given the nature of online media, the Ombudsman concluded that false claims and subjective opinions could not easily be contradicted or refuted. Consequently, the theater director was forced to suffer indefensible damage to his character and irreparable harm to his reputation.

The characterization of the director as a "generally bad guy" served no legally identifiable function (in relation to Criminal Law), nor was it relevant to any of the supposed victims of his alleged actions in a legal sense. As such, publication of the supposedly "bad actions" and the detailed account of the supposed offender's actions, served only the political and financial interests of the newspaper, not justice in any legal sense. The newspaper seemingly took it upon itself to carry-out a derogatory campaign against a single individual outside of the confines of legal rights of the individual.

Other cases and \#MeToo-stories have led to criminal convictions for defamation (sv. förtal eller grovt förtal). Three such cases of special interest are: "the Media Man Case" (Stockholms tingsrätt, B 1755-18), "the Film Director Case" (Nacka tingsrätt B 7995-18), and "the Former Member of Parliament Case" (Södertörns tingsrätt, B 3405-18). All three concerned large-scale defamation cases that gained widespread public attention through all kinds of media platforms, wherein sexual abusers were named indiscriminately, denying them the right to a presumption of innocence until proven guilty by the usual legal system, and convicted in the court of public opinion instead. In the Media Man Case, a famous actress, columnist, and media personality had previously published a detailed story in which she accused an unnamed man - whom she described as "a powerful man of the media" - of a sexual assault she had been forced to suffer after being drugged. The crime had supposedly taken place in 2006. During the early stages of the \#MeToo movement she decided eventually to provide the name of her supposed attacker. She also claimed he was responsible for sexual abuses to other women. Naming or identifying someone as "criminal" to any other 
person constitutes defamation in Swedish Criminal Law, which requires that an accusation can be deemed "defensible" legally. This is intended to maintain a delicate balance between competing legal-criminal interests in any defamation case. The right to name another person as a sexual offender before the legal authorities is a right in itself and, as such, does not constitute defamation, as long as it is supported by the defensibility argument. But in this case, the naming of the offender to a large social media audience went against this legal principle.

The post in which she first named her offender garnered massive support on social media, with conventional news outlets quickly following suit. The Media Man lost his employment as a result. The accuser was subsequently prosecuted for defamation. In its reasons for this verdict, the court referred to the time and place of the defamatory post, noting that the post was directed to a specific audience for a self-serving purpose, and indicating that the accuser's reason for publishing the post was inspired by the \#MeToo movement. But the court stressed that, since she could have served the interests of the movement without naming her supposed perpetrator, her actions were indefensible. Due to the fact that the defamatory posts concerned severe sexual assault, the court concluded that she was to be sentenced for "gross defamation" (sv. "grovt förtal"). The defamatory remarks did not serve a legally identifiable defensible interest. She had the right to name her offender before the legal authorities to have her case tried and heard. The social media exposition of the supposed offender was not deemed an appropriate alternate path for vindication, even when legal means failed.

The Film Director Case was also shaped by social media exposure of a certain individual in lieu of an actual criminal lawsuit or even a civil one against him. The case concerned a single post in two separate forums where the accuser did not directly name the supposed perpetrator. Instead, she indirectly identified him by describing his line of work as a film director, even citing the title of his most famous film. The posts were made in a "closed forum" (although at least 9000 users had access to it). The director was easily identified by forum members and his name shared across a number of open platforms. As a result, the accused lost employment, and his damaged reputation made it virtually impossible for him to pursue any potential future projects with other production studios. The post was made because almost 25 years had passed between the alleged sexual assault and the court proceeding, making it impossible to seek a conviction beyond a reasonable doubt. The court noted, as in the Media Man Case, that the \#MeToo movement itself was not to blame, reasserting that its purpose was to change social and political attitudes, not to allow for grievances to be aired in public. Since the accuser could have used the hashtag to make a general statement, rather than disgracing the identity of the accused, she was given a suspended sentence for gross defamation and forced to pay a fine for substantial damages. As in the previous cases, the \#MeToo-movement is, clearly, in and of itself a legitimate 
political and social justice movement; but it sidesteps legal boundaries by allowing people to use its name for personal reasons.

The third defamation case stands apart from the other two. Whereas the two former cases concerned personal experiences of alleged sexual misconduct, the Former Member of Parliament Case does not. In this case, a politician had identified a co-worker and former member of parliament as a sexual deviant - claiming that he was both a pedophile and a sexual assaulter in a social media post, without concrete evidence. According to her subsequent admission, made in the district court, the aim of her post was to influence his election negatively. The court noted that this attack had nothing to do with the \#MeToo movement. And she too was sentenced for gross defamation to a suspended sentence, fine, and damages. The case is a very rare instance of when someone misused the movement as a platform to serve personal interests without claiming an actual specific interest in the purported criminal behavior. This reinforces our distinction between the \#MeToomovement as a powerful e-discourse one based on the attainment of justice for the victims of sexual abuse, but also as a movement that has given individuals a platform on which to air personal grievances or to sidestep courtroom laws and rules.

Accusations of sexual abuse, misconduct, sexual or violence are still subject to basic principles for the administration of justice. As a sociopolitical movement \#MeToo has been effective in identifying systemic injustices, but it has also lent itself as a form of exculpatory and even vindictive personal forum. It has been used, in other words, as "trial by social media" strategy that was not foreseen by the originators of the movement. The common thread in the cases above is the fact that the rubric of social media activism has made it possible for self-serving accusations to be proffered, free of the ethical constraints, otherwise provided for in Swedish Criminal Law. Nonetheless, it is surprising to find that the Swedish Media Council has remained largely silent on the matter, perhaps because industrybased ethical transgressions have taken place. So far, no actions against social media platforms have taken place in Swedish legal systems. While several sentences in the district courts condemn the actions of certain users, the proprietors of the defamation-generating outlets have not undergone extensive legal scrutiny.

Two highly publicized cases in America, which are strikingly similar to the Swedish ones above, can be added to the present discussion. In one case, a talk show host and journalist was fired from a major media outlet after eight women had accused him of sexual advances and harassment. As reports emphasized, the women were encouraged to come forward by the climate of justice-seeking that was generated by the \#MeToo movement. In effect, the movement had empowered the women to seek justice against the individual, and in so doing, their accusation was seen as vindicating women's subservient plight in sexual politics. In other words, it was seen broadly as a strike against 
the masculinist narrative that had been plaguing American society for centuries. The second case also involved a famous television talk show host, who was fired amid allegations of workplace sexual misconduct. Like the previous case, this one crystallized amid a wave of \#MeToo social media reports of sexual misconduct in the workplace of powerful men in politics and the media. While the accused individual acknowledged having relationships with colleagues, he claimed that they were consensual. As a consequence, he sought his own financial retribution against dismissal. He lost his job and he counter-sued his accusers.

Cases such as those described here have brought about criticism of the \#MeToo movement as focusing too much on cases of individual sexual misconduct, rather than emphasizing the need to change institutional norms that would help those experiencing sexual abuse. Moreover, by focusing on the misdeeds of high-profile public figures, it might have underplayed the stories of regular workers. Even its founder, Tarana Burke, has voiced such misgivings, pointing out that the media attention on the high-profile perpetrators goes against the original aim of the movement to highlight the plight of current and future sufferers (Jeffries 2018). Nonetheless, despite such unfortunate cases as those described here, overall \#MeToo has changed the workplace climate by questioning the "ecosystem" that enables sexual and emotional abuse of women in particular. It has put forth a new narrative of sexual equality that, while having had negative effects in individual cases, has at the very least opened up a discourse that -while needing refinement - has become a socially-wide effective one.

\section{Conclusion}

Using as a primary strategy, a social-media crafted e-discourse, the \#MeToo movement has had considerable effects on social consciousness, while having had various negative ones, as the legal aspects of some of the cases discussed here have brought out. With key phrases such as "women," "survivors," "human rights," "women around the world," and others, it has engendered a powerful form of emotive discourse, to use Roman Jakobson's (1960) wellknown designation, that has been effective in re-shaping perspectives and ideologies with regard to women and their rights. Against the backdrop of the logico-argumentative discourse of courtrooms and legal systems, this type ediscourse has led to changes in attitudes at all levels of society.

Overall, the \#MeToo movement is based on an oppositional discourse challenging remaining residues of rigid patriarchy in cultures throughout the world. Its effectiveness is based on a fundamental principle of language $-\mathrm{a}$ change in the meanings of words and of social narratives leads to a change in perspective. The unique capacity of Twitter hashtags to embed links to groupings of relevant posts has enabled a self-sustaining form of intertextuality, directly linking each post to a broader conversation and therefore encouraging collective engagement, which aims to foster a new form of 
gender consciousness. Within the \#MeToo e-discourse, the sharing of experiences of sexual harassment and assault, accompanied by themes of consent, bodily autonomy, and violations of this autonomy, provide an alternative conceptual framework within which women and other survivors can label and articulate their experiences; in other words, it renders sexual abuse based on power dynamics concrete and thus open to deconstruction.

From the legal point of view the movement has had both positive and negative effects, as discussed in this article. From the current procedural law perspective, it has shown the negative consequences of the use of social media trials for punitive purposes - a fact that has plagued the \#MeToo movement since its inception. These pose a risk to real justice, recalling previous shaming trials and campaigns that need not concern us here. Injustices have, in effect, been carried out because of the misuse of the movement. And this is the reason why, perhaps, the movement has receded somewhat from the mainstream. The movement works best as a discourse channel for garnering support for needed radical structural changes in social attitudes and the law. However, it fails to be effective when it focuses on individual scandals and permits the venting of grievances, as Tarana Burke has herself suggested.

In sum, \#\#MeToo as an e-discourse has subsided in the face of other global problems, such as pandemics and climate change. Although the movement has had a concrete impact on raising issues of social justice for women, it has not really impugned legal systems based on the principles discussed here. It has primarily shed light on their operations. As such, it remains a discursive movement, rather than a strictly legal one.

\section{References}

Aftonbladet, exp. nr. 12/2019, dnr. 18176.

Anderson, Monica \& Skye Toor (2018), How Social Media Users Have Discussed Sexual Harassment Since \#MeToo Went Viral. Pew Research Center. 11 Oct. 2018. https://www.pewresearch.org/fact-tank/2018/10/ 11/how-social-media-users-have-discussed-sexual-harassment-sincemetoo-went-viral/.

Asp, Petter \& Ulväng, Magnus (2014), Straffrätt. Uppsala: Iustus.

Asp, Petter, Ulväng, Magnus \& Jareborg, Nils (2010), Kriminalrättens grunder. Uppsala: Iustus.

Bakhtin, Mikhail (1981), The Dialogic Imagination. Austin: University of Texas Press.

Berglund, Kerstin (2007), Straffrätt och kön. Uppsala: Iustus.

Bourdieu, Pierre (1980), The Logic of Practice. Stanford: Stanford University Press.

Brå Rapport 2020:2, (2020), Anmälda och uppklarade våldtäkter $i$ Europa. Stockholm: Norstedts Juridik.

Burke, Tarana (n.d.), The Inception. Justbeinc. https://justbeinc.wixsite.com/ justbeinc/the-me-too-movement-cmml. 
Buxton, Madeline (2018), With Me Too Rising, Google Maps The Spread Of A Movement. Refinery29, Vice Media Group. www.refinery29.com/enus/2018/04/196748/me-too-google.

Caputi, Theodore L., Nobles, Alicia L. \& Ayers, John W. (2019), Internet Searches for Sexual Harassment and Assault, Reporting, and Training Since the \#MeToo Movement, JAMA Internal Medicine 179, s. 258-259.

Charles, Thalia (2018), The White Washing of \#MeToo, Medium: Period Movement. https://medium.com/periodmovement/the-white-washing-ofmetoo-bf778620f29.

Christie, Nils (1977), Konflikt som eiendom, Tidskrift för rettsvitenskap, s. 113132.

Christie, Nils \& Bruun, Kettil (1986), Hyvä vihollinen: huumausainepolitiikka Pohjolassa. Espoo, Weilin + Göös.

The Criminal Code of the Russian Federation, Article 16.

The Council of Europe Convention on preventing and combating violence against women and domestic violence (Istanbul Convention), CETS 210, Istanbul, 11.V.2011.

Danesi, Marcel (2016), Discourse, Dialogue, and Conversation: A Schematic Overview, i Case Studies in Discourse Analysis, s. 1-26. München: Lincom Europa.

The Declaration on the Elimination of Violence against Women Proclaimed by General Assembly resolution 48/104 of 20 December 1993.

Diesen, Christian \& Diesen, Eva F. (2013), Övergrepp mot kvinnor och barnden rättsliga hanteringen, 2 uppl., Vanda: Norstedts Juridik.

Ervasti, Kaijus (2002), Lainkäytön funktiot, Lakimies 2002, s. 47-72.

Ervo Laura (2005), Kommunikation i en rättvis rättegång, speciellt muntlighetens betydelse vid domstol, i Eric Bylander \& Per Henrik Lindblom (red.) Muntlighet vid domstol i Norden: en rättsvetenskaplig, rättspsykologisk och rättsetnologisk studie av presentationsformernas betydelse $i$ förfarandet vid domstol $i$ Norden. Uppsala: Iustus.

Ervo, Laura (2005), Oikeudenmukainen oikeudenkäynti. Helsinki: WSOY.

Ervo, Laura (2008), Oikeudenkäynnin oikeudenmukaisuusvaatimuus. Käsikirja lainkäyttäjille. Helsinki: WSOY.

Ervo, Laura (2014), Nordic Court Culture in Progress: Historical and Futuristic Perspectives, i L. Ervo and A. Nylund (red.), The Future of Civil Litigation. Cham: Springer.

Ervo, Laura \& Dahlqvist, Amie (2014), Delays in Civil Proceedings: Comparative Studies Between Finland and Sweden, i L. Ervo and A. Nylund (red.) The Future of Civil Litigation. Cham: Springer.

Fairclough, Norman (2003), Analysing Discourse: Textual Analysis for Social Research. London: Routledge.

Fredman, Markku (2002), Rikosasioiden julkisuus, Oikeus 2002, s. 303-309.

Frände, Carolina (2018), Jag vill bryta tystnaden efter Benny Fredrikssons död. Svenska Dagbladet. 5 May 2018. https:/www.svd.se/om/benny-fredriks son [2021-03-01].

Government Bill 2004/05:45, En ny sexuallagstiftning.

Government Bill 2017/18:177 En ny sexuallagstiftning byggd på frivillighet. 
Green, Jeff (2018), \#MeToo Snares More Than 400 High-Profile People. Bloomberg 25 juni 2018. https://www.bloomberg.com/news/articles/ 2018-06-25/-metoo-snares-more-than-400-high-profile-people-as-firingsrise.

Gustavsson, Matilda (2019), Klubben. Stockholm: Bonnier.

Harris, Aisha (2018), She Founded Me Too. Now She Wants to Move Past the Trauma, The New York Times, 15 oktober 2018. www.nytimes.com/ 2018/10/15/arts/tarana-burke-metoo-anniversary.html..

Jakobson, Roman (1960), Linguistics and Poetics, i T. A. Sebeok (red.), Style and Language 34-45. Cambridge, Mass.: MIT Press.

Jareborg, Nils \& Ulväng, Magnus (2016), Tanke och uppsåt. Uppsala: Iustus.

Jeffries, Zenobia (2018), Me Too Creator Tarana Burke Reminds Us This is About Black and Brown Survivors, YES! Magazine 4 Jan. 2018. http://www.yesmagazine.org/people-power/me-too-creator-tarana-burkereminds-us-this-is-about-black-and-brown-survivors-20180104.

Kastula, Teemu (2009), Rikosasioiden kohtuullinen käsittelyaika ja rikosoikeudenkäyntien viivästymistä vastaan olevat tehokkaat oikeussuojakeinot erityisesti Euroopan ihmisoikeussopimuksen ja ihmisoikeustuomioistuimen oikeuskäytännön valossa. Master's Thesis 22 Oct. 2009, University of Helsinki, Faculty of Law, Department of Criminal Law, Procedural Law and General Jurisprudential Studies. Published in Edilex 3 March 2010. http://www.edilex.fi/lakikirjasto /6859.

Keyword Search: \#MeToo. Twitter 29 April 2020. https://witter.com/search?q $=\#$ MeToo\&src=typed_query.

Laitinen, Ahti (2002). Oikeussosiologian perusteet. Turku: Turun yliopiston oikeustieteellinen tiedekunta.

Leppänen, Tatu (1998), Riita-asiain valmistelu todistusaineiston osalta. Suomalainen Lakimiesyhdistys.

Lindblom, Per Henrik (2000), Processens funktioner - en resa i gränslandet, i Progressive Process. Spridda uppsatser om domstolsprocessen och samhällsutveclingen, s. 41-85. Uppsala: Iustus.

Lindell, Bengt (2003), Civilprocessen. Uppsala: Iustus.

Melander, Sakari (2019), Rikos, julkisuus ja yksityisyyden suoja. Lakimies 2019, s. 953-983.

Me Too Rising (n.d.), Google, Google, metoorising.withgoogle.com/about.

Milano, Alyssa. Twitter post. 15 Oct. 2017, 4:21pm. https://twitter.com/ Alyssa_Milano/status/919659438700670976.

Nicolaou, Elena \& Smith, Courtney E. (2019), A \#MeToo Timeline To Show How Far We've Come \& How Far We Need To Go. Refinery29. Vice Media Group. 7 Oct. 2019. www.refinery29.com/en-ca/2019/10/8534374 /a-metoo-timeline-to-show-how-far-weve-come-how-far-we-need-to-go.

Ortner, Sherry B. (2006), Anthropology and Social Theory: Culture, Power, and the Acting Subject. Durham: Duke University Press.

The 1864 Penal Code 15:12.

Rouhiainen Minna (2014), Oikeudenkäynnin viivästymisen hyvittäminen ja hyvityslaki erityisesti rikosprosessin kannalta. Pro gradu-tutkielma. 
Joulukuu 2014, Helsingin yliopisto. Oikeustieteellinen tiedekunta Published in Edilex 8.5.2015 www.edilex.fi/opinnaytetyot/15177.

Santucci, Jeanine (2020), Former Staffer Tara Reade Says Joe Biden Sexually Assaulted Her in 1993. Here's What We Know. USA Today 28 Apr. 2020. https://www.usatoday.com/story/news/politics/elections/2020/04/28/joebiden-sexual-assault-allegation-what-we-know-tara-reade/3039909001/.

SFS 1962:700 The Criminal Code 1:2.

SFS 1962:700 The Criminal Code chapter 5.

SFS 2018:618 The Criminal Code 6:1-3.

Virolainen, Jyrki (1995), Lainkäyttö. Helsinki: Lakimiesliiton Kustannus.

Vuorenpää, Mikko (2001), Målsägandens rättigheter i Finland. Några kritiska synpunkter. JFT 2001/2-3.

Warshawsky, Jana (2019), Activists Talk Whitewashing of \#MeToo Movement, How It Progressed Internationally. Washington Square News. October 3 2019. https://nyunews.com/news/2019/10/02/news-discussing-metootransnationally/.

\section{Case Law:}

Svea Hovrätt, B 6863-18.

Stockholms tingsrätt, B 15565-17.

Svea Hovrätt, B 9085-18.

Stockholms tingsrätt, B 1755-18.

Nacka tingsrätt, B 7995-18.

Södertörns tingsrätt, B 3405-18. 